\title{
SOIL WATER EVAPORATION UNDER DENSITIES OF COVERAGE WITH VEGETABLE RESIDUE
}

\section{RICARDO GAVA ${ }^{1}$, PAULO S. L. DE FREITAS ${ }^{2}$, ROGÉRIO T. DE FARIA ${ }^{3}$, ROBERTO REZENDE ${ }^{2}$, JOSÉ A. FRIZZONE ${ }^{4}$}

\begin{abstract}
This study was conducted at the Agronomic Institute of Paraná (IAPAR) in Londrina, State of Paraná (PR), Brazil (latitude $23^{\circ} 18^{\prime} \mathrm{S}$, longitude $51^{\circ} 09^{\prime} \mathrm{W}$ and average altitude of $585 \mathrm{~m}$ ). The local climate, according to the classification of Köeppen, is Cfa type, i.e., humid subtropical climate, with rain in all seasons and can occur dry seasons during the winter. It was determined soil evaporation (E) under different coverage densities with residue from the wheat crop. The treatments were installed in weighting lysimeters of $2.66 \mathrm{~m}^{2}$ and $1.3 \mathrm{~m}$ deep, which allows to determine $\mathrm{E}$ by the mass difference with measuring precision of $0.1 \mathrm{~mm}$ at one hour intervals. Treatments consisted of $0 ; 2.5 ; 5$ and $10 \mathrm{tha}^{-1}$ of wheat crop residues, placed evenly over each lysimeter. In the first cycle (September $22^{\text {nd }}$ to October $20^{\text {th }}, 2008$ ), the reduction of E, as compared to a bare soil, was $4 ; 15$ and $24 \%$, while in the second cycle (December $1^{\text {st }}$ to $30^{\text {th }}, 2008$ ), the reduction was of $15 ; 22$ and $25 \%$, respectively, for the treatments of $2.5 ; 5$ and $10 \mathrm{tha}^{-1}$.
\end{abstract}

KEYWORDS: wheat straw, soil coverage, water losses.

\section{EVAPORAÇÃO DA ÁGUA DO SOLO EM FUNÇÃO DA DENSIDADE DE COBERTURA COM RESÍDUO VEGETAL}

RESUMO: O presente estudo foi realizado no Instituto Agronômico do Paraná (IAPAR), em Londrina, Estado do Paraná (latitude de $23^{\circ} 18^{\prime} \mathrm{S}$, longitude de $51^{\circ} 09^{\prime} \mathrm{W}$ e altitude média de $585 \mathrm{~m}$ ). O clima local, segundo a classificação do Köppen, é do tipo Cfa, ou seja, subtropical úmido, com chuvas em todas as estações, podendo ocorrer secas no período de inverno. Determinou-se a evaporação (E) da água do solo sob diferentes densidades de cobertura com resíduo da cultura de trigo. Os tratamentos foram instalados em lisímetros de pesagem de $2,66 \mathrm{~m}^{2}$ e $1,3 \mathrm{~m}$ de profundidade, que permitem determinar E por diferença de massa com precisão equivalente a $0,1 \mathrm{~mm}$ em intervalos de uma hora. Os tratamentos consistiram em $0 ; 2,5 ; 5$ e $10 \mathrm{t} \mathrm{ha}^{-1}$ de resíduos da cultura do trigo, colocadas de forma homogênea em cada lisímetro. No primeiro ciclo (22/09 a 20/10/2008), a redução de E em relação ao solo descoberto foi de $4 ; 15$ e $24 \%$, enquanto no segundo ciclo (01/12 a 30/12/2008), a redução foi de $15 ; 22$ e $25 \%$, respectivamente, para os tratamentos 2,$5 ; 5$ e $10 \mathrm{t} \mathrm{ha}^{-1}$.

PALAVRAS-CHAVE: palha de trigo, cobertura do solo, perdas de água.

\section{INTRODUCTION}

Irrigated agriculture is considered one of the activities that use the most water, becoming increasingly important studies on the most efficient use of water by plants.

The evaporation is a major form of loss of water in a soil, especially in tropical countries such as Brazil. Therefore, we must seek an agricultural management that minimizes losses through evaporation.

The biomass production is of fundamental importance for the no-tillage system (NTS), which is one of the most effective practices for better utilization of the available water in the soil.

\footnotetext{
${ }^{1}$ LEB/ ESALQ-USP, Av. Pádua Dias, 11, Piracicaba - SP, Fone: (OXX19)3447-8541, gava_ricardo@yahoo.com.br.

2 DAG/ UEM, Av. Colombo, 5790, Maringá - PR, Fone: (0XX44) 3261-8916, pslfreitas@uem.br; rrezende@uem.br.

${ }^{3}$ Prof. Dr., FCAV/UNESP, Câmpus de Jaboticabal - SP, Fone: (OXX16) 3209-2637, rtfaria@ unesp.br.

${ }^{4}$ ESALQ-USP, Av. Pádua Dias, 11, Piracicaba - SP, Fone (0XX19)-3447-8544, frizzone@ esalq.usp.br.

Recebido pelo Conselho Editorial em: 20-9-2011
}

Aprovado pelo Conselho Editorial em: 5-9-2012 
According to GAVA et al. (2009) while the straw can help to reduce water evaporation from the soil, it retains part of the water applied or precipitated in the area. A tillage system with $10 \mathrm{tha}^{-1}$ of wheat straw can hold up to $1.5 \mathrm{~mm}$ of water that is transferred to the atmosphere in the form of evaporation without contributing to the storage of water in the soil. Therefore, an irrigation system that applies small blades with high frequency will lose much of the water applied by direct evaporation in the straw.

For residues of maize crop, FREITAS et al. (2004) found retention of water by the residue after the application of a $20 \mathrm{~mm}$ depth, corresponding to $1.2 ; 1.4$ and $1.8 \mathrm{~mm}$, respectively, for coverage conditions of 4.8; 6.3 and $10 \mathrm{t} \mathrm{ha}^{-1}$. The authors also reported that the amount of water retained by the waste may be significant in irrigation systems with high frequency of application, which causes the proportion of evaporated water relatively high.

SILVA et al. (2006) observed that straws of millet and maize had higher water storage capacity than soybeans: $3.26 ; 3.24$ and $2.62 \mathrm{~g}$ of water per $\mathrm{g}$ of straw, respectively.

Working with loss of water by evaporation in a soil cultivated with maize in no-tillage and conventional system, ANDRADE et al. (2007) found reduction of water losses of 19 and $42 \%$, respectively, for 3 and $6 \mathrm{t} \mathrm{ha}^{-1}$ of oat crop residues compared to the seeding in bare soil.

The use of weighting lysimeters to determine the evapotranspiration is very accurate. FARIA et al. (2006), working with the construction and calibration of lysimeters of high accuracy, found excellent linearity between the variations of mass and electric voltage for all ten lysimeters tested and there was no hysteresis. The evapotranspiration measurements showed precision to detect changes in mass equivalent to $0.1 \mathrm{~mm}$ at intervals equal to or greater than $1 \mathrm{~h}$, adjusted for most field applications.

However, SILVA et al. (1999) warn that, in the time period from 6 a.m. to 11 a.m., small increases occur in the readings of the system which can be attributed to the influence of temperature changes on the load cell.

Despite the high accuracy of the load cell and data acquisition system, the measures taken for several days after the construction of the lysimeters indicated that the rain reduces measurement accuracy during periods with rain and the wind is the most limiting factor for obtaining measures with high temporal resolution of less than 10 min (CAMPECHE, 2002).

The aim of this study was to measure the evaporation of water from soil under fallow and different densities of soil coverage with wheat straw in order to quantify the reduction of evaporation due to the amount of crop residues in the region of Londrina - state of Paraná (PR), Brazil.

\section{MATERIAL AND METHODS}

This study was conducted at the Agronomic Institute of Paraná (IAPAR) in Londrina-PR, (latitude $23^{\circ} 18^{\prime} \mathrm{S}$, longitude $51^{\circ} 09^{\prime} \mathrm{W}$ and average altitude of $585 \mathrm{~m}$ ). The climate of Londrina, according to the Köppen classification, is a Cfa, i.e., subtropical humid, with rain in all seasons, dry seasons can occur during winter. The average temperature of the warmest month is above $22{ }^{\circ} \mathrm{C}$ and the coldest month is below $18{ }^{\circ} \mathrm{C}$. The soil is classified as Eutroferric Red Latosol, according to EMBRAPA (2006). The soil gradation is compound of: $6 \%$ sand, $13 \%$ silt and $81 \%$ clay.

The measurements of evaporation under different densities of crop residues were held in eight weighting lysimeters kept in fallow, installed near the weather station of the Institute SIMEPAR. These lysimeters are composed by impermeable metal tanks, with dimensions of $1.4 \mathrm{~m}$ wide, $1.9 \mathrm{~m}$ long and $1.3 \mathrm{~m}$ deep and with local soil, placed at ground level under a scales consisting of a lever system for mass reduction. The lysimeters detects mass variations equivalents to the depth of $0.1 \mathrm{~mm}$ at intervals up to $1 \mathrm{hr}$, measured by load cell that emits electric signals with a sensitivity of $2+/-10 \% \mathrm{mV} \mathrm{V}^{-1}$ and an accuracy of $0.02 \%$ of full scale. Readings are made every three seconds, 
collecting 200 values in $10 \mathrm{~min}$ and the data acquisition system stores the average of this interval to prevent variations mainly caused by the wind.

Measurements of the electrical signals were transferred from the data acquisition system through a digital interface to a computer to be converted to mass unit and then to depth unit (mm) using equations of the initial calibration of each lysimeter.

The evaporation values were determined by the balance of the inputs, outputs, and the water storage in the lysimeters, according to the following equation:

$$
\mathrm{E}=\mathrm{P}+\mathrm{I}-\mathrm{R}-\mathrm{D} \pm \Delta \mathrm{A}
$$

In which,

E - evaporation, mm;

$\mathrm{P}$ - precipitation, $\mathrm{mm}$;

I - irrigation, $\mathrm{mm}$;

$\mathrm{R}$ - runoff, mm - considered zero due to the edge of the lysimeter tank;

$\mathrm{D}$ - drain, mm, and

$\Delta \mathrm{A}$ - storage variation given by the difference in mass during the period, $\mathrm{mm}$.

The reference evapotranspiration was calculated by Penman-Monteith method (ALLEN et al. 1998), using daily data obtained from automatic weather station.

$$
\text { ETo }=\frac{0.408 \Delta .40-\mathrm{G})+\gamma \frac{900}{(\mathrm{~T}+273)} \mathrm{U}_{2}(\mathrm{es}-\mathrm{ea})}{\Delta+\gamma\left(1+0.34 \mathrm{U}_{2}\right)}
$$

In which,

ETo - reference evapotranspiration, $\mathrm{mm} \mathrm{d}^{-1}$;

$\mathrm{Rn}$ - radiation balance to the surface, $\mathrm{MJ} \mathrm{m}^{-2} \mathrm{~d}^{-1}$;

$\mathrm{G}$ - heat flow sensitive to the soil, $\mathrm{MJ} \mathrm{m}^{-2} \mathrm{~d}^{-1}$;

$\mathrm{T}$ - average air temperature at $2 \mathrm{~m}$ height, ${ }^{\circ} \mathrm{C}$;

$\mathrm{U}_{2}$ - wind velocity at $2 \mathrm{~m}$ height, $\mathrm{m} \mathrm{s}^{-1}$;

$\mathrm{e}_{\mathrm{s}}$ - steam saturation pressure, $\mathrm{kPa}$;

$\mathrm{e}_{\mathrm{a}}$ - current steam pressure, $\mathrm{kPa}$;

$\Delta$ - curve declivity of saturation pressure, $\mathrm{kPa}^{\circ} \mathrm{C}^{-1}$, and

$\gamma$ - psychometric constant, $\mathrm{kPa}^{\circ} \mathrm{C}^{-1}$.

Was determined the evaporation with bare soil $\left(0 \mathrm{t} \mathrm{ha}^{-1}\right)$ and three quantities of wheat crop residues $\left(2.5 ; 5\right.$ and $\left.10 \mathrm{t} \mathrm{ha}^{-1}\right)$ during two cycles of drying, (09/22 to 10/20/2008 and 12/01 to 12/30/2008).

After drying the straw in a stove of forced air circulation for 48 hours at $65{ }^{\circ} \mathrm{C}$ it was determined quantities of $0.665 ; 1.330$ and $2.660 \mathrm{~kg}$, equivalent to $0 ; 2.5 ; 5$ and $10 \mathrm{t} \mathrm{ha}^{-1}$ of dry matter (Figure 1).

To determine the coefficient of evaporation of the soil water $\left(\mathrm{K}_{\mathrm{e}}\right)$ it was obtained daily values of evaporation measured on the weighting lysimeters. According to ALLEN et al. (2005) when the soil surface is completely wet by rain or irrigation and soil fraction effectively exposed to the energy of evaporation. In this case is $100 \%$ of the lysimeter area, because there were no plants. The equation presented by ALLEN et al. (2005) is:

$\mathrm{K}_{\mathrm{c}_{\mathrm{act}}}=\mathrm{K}_{\mathrm{S}} \mathrm{K}_{\mathrm{cb}}+\mathrm{K}_{\mathrm{e}}$ and Etc $=\left(\mathrm{K}_{\mathrm{s}} \mathrm{K}_{\mathrm{cb}}+\mathrm{K}_{\mathrm{e}}\right)$ ETo and the value of $\mathrm{K}_{\mathrm{e}}$ can be calculated by the equation $\mathrm{K}_{\mathrm{e}}=\frac{\mathrm{E}}{\mathrm{ETo}}$. 
In which,

$\mathrm{K}_{\mathrm{s}}$ - coefficient of soil humidity deficit, dimensionless;

$\mathrm{K}_{\mathrm{cb}}$ - basal coefficient of crop, dimensionless;

$\mathrm{K}_{\mathrm{e}}$ - coefficient of evaporation, dimensionless, and

Etc - evapotranspiration of the crop, $\mathrm{mm} \mathrm{d}^{-1}$.

A

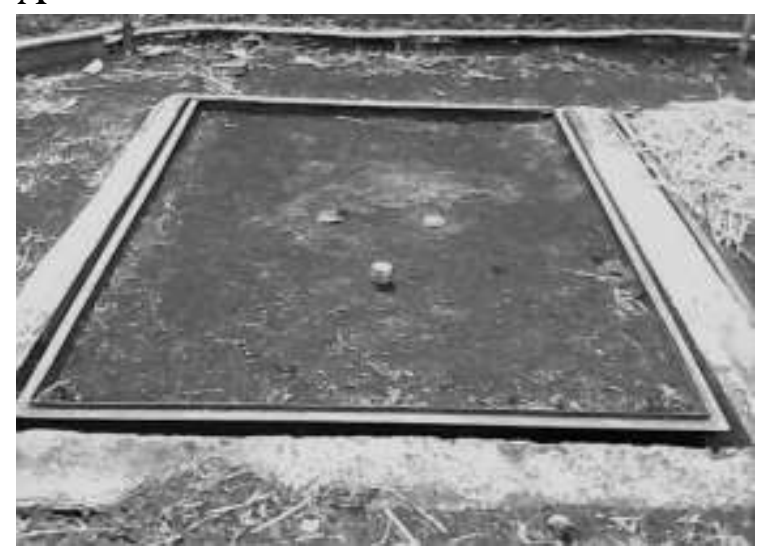

C

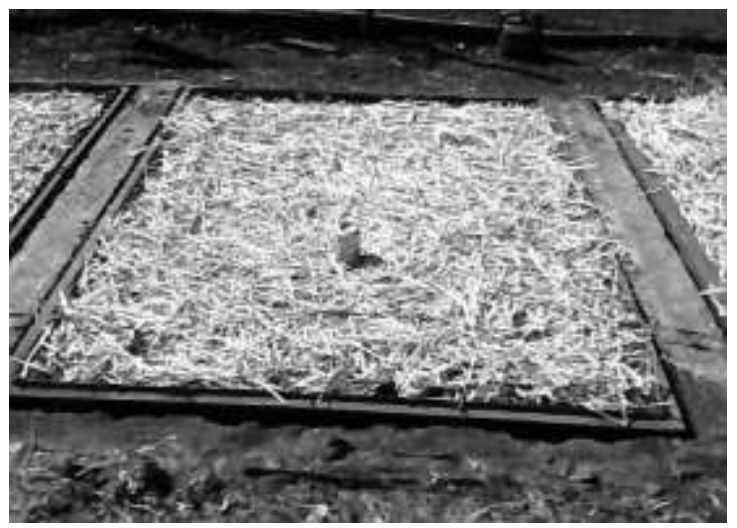

B

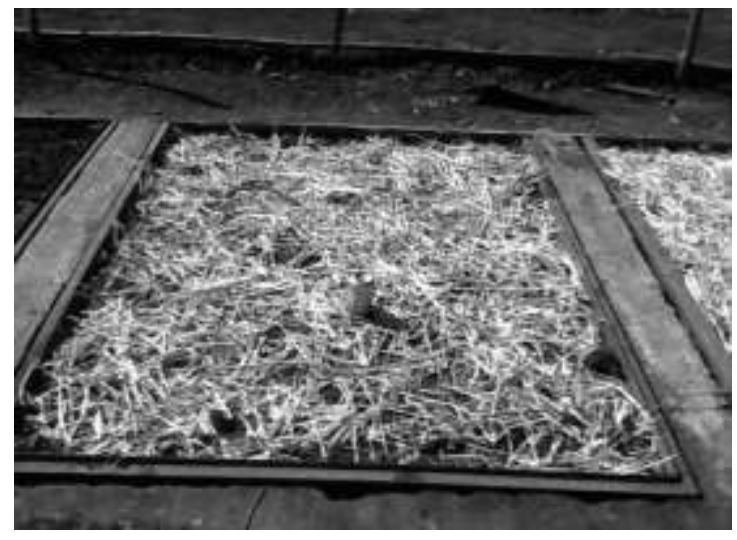

$\mathrm{D}$

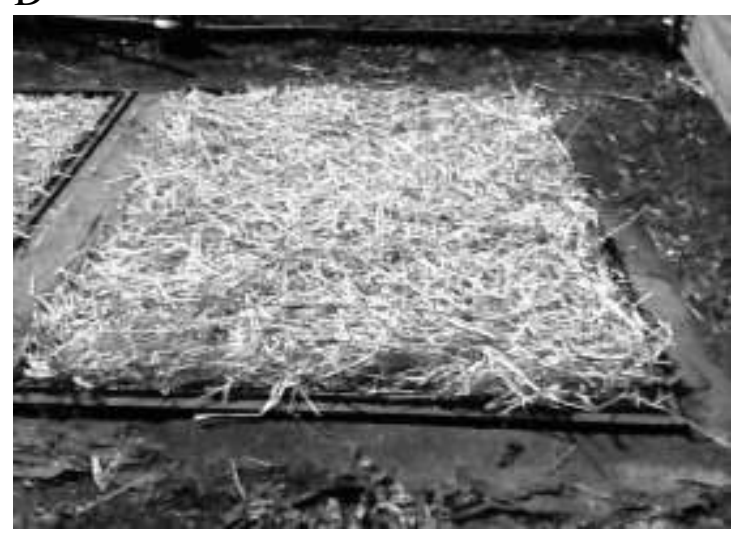

FIGURE 1. Lysimeter on bare soil (A) and lysimeters with different densities of soil coverage with wheat straw: 2.5 (B), 5 (C) and 10 ton $\mathrm{ha}^{-1}(\mathrm{D})$.

\section{RESULTS AND DISCUSSION}

\section{Daily values of evaporation}

Figure 2 shows the daily values of evaporation $\left(\mathrm{mm} \mathrm{d}^{-1}\right)$, for different densities of wheat straw, 0; 2.5; 5 and $10 \mathrm{t} \mathrm{ha}^{-1}$, and reference evapotranspiration, between 09/22 and 10/20/2008 (first cycle).

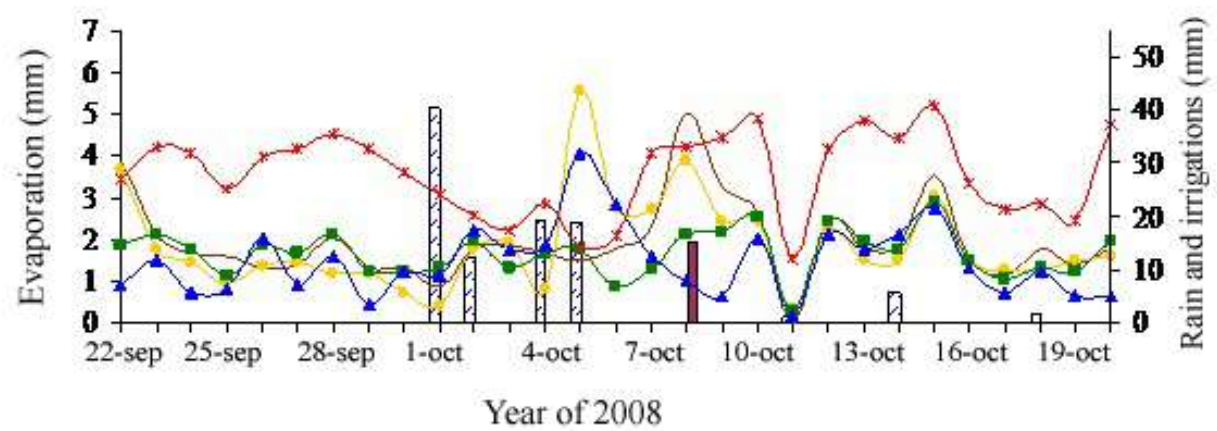

$\square$ rain $\square \rightarrow 2,5 \rightarrow-5 \rightarrow 10 \rightarrow-$ Eb

FIGURE 2. Reference evapotranspiration and evaporation under three densities of soil coverage with wheat straw, during the first cycle. 
In the first cycle of evaporation, rains and irrigation amounted to approximately $115 \mathrm{~mm}$. Although most of the rain of the cycle, of $40.4 \mathrm{~mm}$, occurred on 10/01/08, the rain only began at 5 p.m., extending up to 2 hours on 10/02/08. So this day started with the ground surface very humid, resulting in evaporation rates higher than the previous days, as it can be seen in Figure 2 . The changes that occurred in the evaporation of water from the soil, from 09/22 to 10/01/08, in the residue treatment, were due to the variation of atmospheric demand for water.

One day after a rain on 10/01 and 10/02/08, there was more evaporation in treatments with more straw (10 t). On 10/04/08 the rain was distributed throughout the day, being recorded rain at 4 a.m., 11 a.m. and 4 p.m., amounting $19.2 \mathrm{~mm}$. Again it was observed that treatment with higher amounts of straw presented larger evaporations. From 10 p.m. there was more rain and these occurred until 5 p.m. on 10/05/08. The discrepancies of the occurrence of increased evaporation at higher amount of straw may be attributed to errors of lysimeters during periods with precipitation, as evidenced by several studies published (CAMPECHE, 2002; FARIA et al., 2006). In the present experiment, this failure is evidenced, on $10 / 05 / 08$, by the values of evaporation in the treatment with 10t of approximately three times larger than ETo.

On10/08/08 there was irrigation with $15 \mathrm{~mm}$ at 11 a.m., resulting in increased evaporation of the bare soil above the value of ETo. On 10/11/08 remained cloudy all day with rain of $1.1 \mathrm{~mm}$. This caused the evaporation of the next day return to the same rate presented in the previous day, 10/11, due to increased moisture in the soil surface. On10/14/08 there was a slight precipitation of $5.6 \mathrm{~mm}$ in the late afternoon, resulting in increased evaporation on day 15 for all treatments. At the daybreak of the 18th day there was a very small rain of $0.8 \mathrm{~mm}$, increasing the evaporation mainly from the bare soil. In the late afternoon rained again, but only about $1 \mathrm{~mm}$.

Figure 3 shows the daily values of evaporation $\left(\mathrm{mm} \mathrm{d}^{-1}\right)$ at different densities of soil coverage with wheat straw, 0;2.5; 5 and $10 \mathrm{t} \mathrm{ha}^{-1}$, and reference evapotranspiration, between 12/01 and $12 / 30 / 2008$ (second cycle).

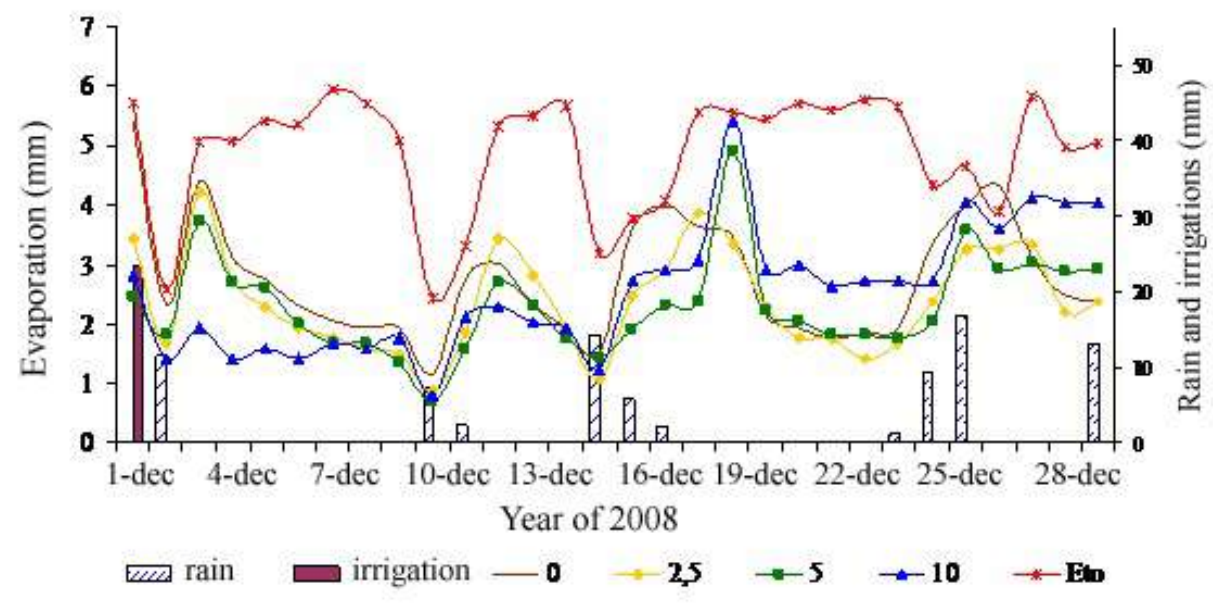

FIGURE 3. Reference evapotranspiration and evaporation under three densities of soil coverage with wheat straw, during the second cycle.

The second cycle had a cumulative rainfall of $106 \mathrm{~mm}$, starting with irrigation at 9 a.m. on12/01/08, with applied depth of $23 \mathrm{~mm}$. Because of this, the evaporation in all treatments was high. In the following day, it rained in the morning and in the afternoon, and on 12/03/08 initiated humid and having high evaporation. After 7 days without rain, it was observed that treatment with $10 \mathrm{t} \mathrm{ha}^{-1}$ had lower evaporation rates than the other treatments, a fact that confirms PREVEDELLO \& LOYOLA (2005), simulating the evaporation process, found that sand placed on the soil surface, behaves as an insulating layer ("mulching"), providing strong resistance to the flow of water on the soil surface. Also GONÇALVES et al. (2005) evaluated the water consumption of lettuce crop with the soil covered with polyethylene film, and observed water consumption about $34 \%$ lower compared to the lettuce which treatment did not have the soil covered with plastic. 
Also SOARES et al. (2001) analyzed the dependence of crop coefficient for the initial development stage $\left(\mathrm{K}_{\mathrm{cini}}\right)$ to water depth and soil texture. The direct evaporation of water from the soil (Es) was determined using the model of Ritchie. They concluded that for low values of ETo to $4 \mathrm{~mm} \mathrm{~d}^{-1}$, the evaporation of water from the soil is superior in loamy soils with application of water depths greater than $15 \mathrm{~mm}$ and under the same climatic conditions and wetting, the soil of fine texture presents $\mathrm{K}_{\mathrm{cini}}$ greater than the thick textured soil.

On 12/10/08 remained cloudy and the rain was recorded between 9 a.m. and 3 p.m. On the morning of 12/11/08 there was more rain, making the surface of the soil very humid in the early morning, causing a large increase of the evaporation.

On 12/15/08 there was rain between 11 a.m. and 2 p.m., returning to precipitate at 7 p.m. Thus, on 12/16/08 began with enough water available and rain of $5.9 \mathrm{~mm}$ at 2 p.m. made $\mathrm{E}$ increase in the treatment with bare soil, followed by the treatment with more amount of straw. The same repeated on $12 / 17 / 08$.

On $12 / 19 / 08$, the lysimeters containing 5 and $10 \mathrm{t} \mathrm{ha}^{-1}$ showed problem on the load cells, since in the time between 9 and $10 \mathrm{a} . \mathrm{m}$. there was an increase of 2.7 and $2.9 \mathrm{~mm}$, respectively for these treatments. From this day the lysimeter with $10 \mathrm{t} \mathrm{ha}^{-1}$ continued to show discrepant values.

On 12/24/08 was a dry day, but late at night the rain began and lasted until 1a.m. of the next day, 12/25/08. On 12/25/08 started with high humidity from the surface layer, and combined with the 2 p.m. rain, caused the bare soil to present the highest values of evaporation. On the night of $12 / 25 / 08$, more rain occurred resulting again in higher evaporation for treatments with bare soil and $10 \mathrm{t} \mathrm{ha}^{-1}$ on $12 / 26 / 08$. On this day there was rain in the late afternoon making the day $12 / 27 / 08$ begin with high humidity and the soil $\mathrm{E}$ of the bare soil overcome the ETo, followed by treatment with more straw, leaving again the exception to discrepant data presented by this lysimeter treatment, which is reinforced by the results, on this same day 12/27/08, of the lysimeters of the other treatments, while on the treatment with $5 \mathrm{tha}^{-1}$ the evaporation was lower than the $2.5 \mathrm{tha}^{-1}$.

\section{Accumulated values of evaporation}

In general, as the daily ETo increases, the values of evaporation also increase. However, the evaporation of each treatment depends on the soil humidity, i.e. the amount of water present on the soil, liable to evaporate and also the effects of the straw on these treatments. Due to the complexity of analyze daily each effect of evaporation increase or decrease, we tried to analyze the accumulated value of the cycle, to thereby determine the best results in the reduction of evaporation of each treatment.

The accumulated values of evaporation on the different densities of soil coverage with wheat straw are shown in Table 1.

TABLE 1. Cumulative values of evaporation under three densities of soil coverage with wheat straw.

\begin{tabular}{|c|c|c|c|c|c|c|c|c|c|c|}
\hline & & \multicolumn{3}{|c|}{$\begin{array}{l}\text { First Cycle } \\
\text { t ha }^{-1}\end{array}$} & \multicolumn{6}{|c|}{$\begin{array}{l}\text { Second Cycle } \\
\mathrm{t} \mathrm{ha}^{-1}\end{array}$} \\
\hline & 0 & 2.5 & 5 & 10 & ETo & 0 & 2.5 & 5 & 10 & ETo \\
\hline Cumulative values (mm) & 56.4 & 54.0 & 48.2 & 42.7 & 103.7 & 53.6 & 45.6 & 42.0 & 40.0 & 147.3 \\
\hline Reduction in relation to the bare soil (\%) & 0.0 & 4.2 & 14.6 & 24.3 & & 0.0 & 14.9 & 21.6 & 25.3 & \\
\hline Reduction in relation to the ETo (\%) & 45.6 & 47.9 & 53.5 & 58.8 & & 44.3 & 52.6 & 56.4 & 58.5 & \\
\hline
\end{tabular}

The sum of rainfall and irrigation in the first period reached $115.2 \mathrm{~mm}$, but were concentrated in the middle of the cycle. It can be observed in Table 1, the first cycle, that there was little effect of treatment with $2.5 \mathrm{t} \mathrm{ha}^{-1}$, with accumulated evaporation of it practically equal to the control with bare soil. 
In the first cycle the reduction of the evaporation was about $4 \%$ for treatment with $2.5 \mathrm{t} \mathrm{ha}^{-1}$ whereas for 5 and $10 \mathrm{t} \mathrm{ha}^{-1}$ approached of 15 and $24 \%$, respectively, corroborating data obtained by FREITAS et al. (2004).

Considering the values presented in Table 1, making in relation to ETo, the percentage of reduction obtained for the first cycle were 45.6; 47.9; 53.5 and $58.8 \%$ for bare soil treatments with 2.5; 5 and $10 \mathrm{t} \mathrm{ha}^{-1}$, respectively, while for the second cycle were 44.3; 52.6; 56.4 and 58.5, respectively, the values for the second cycle were calculated based on the data accumulated until $12 / 19 / 2008$, because from this date, the lysimeter with $10 \mathrm{t} \mathrm{ha}^{-1}$ of straw density presented issues in the readings.

These results are superior to those found by XIE et al. (2006) who obtained the ratio between the soil water evaporation and the evapotranspiration of $40.7 \%$ during the cycle of the watermelon culture for the treatment without coverage and 17.8 to $25 \%$ for the treatment with sand and gravel coverage, to milder climate conditions with annual maximum temperature of $20.7^{\circ} \mathrm{C}$.

Unlike the first cycle, the accumulated data of the second cycle show values of evaporation on bare soil always higher than the other treatments. It is important to note that, although the depth of rainfall during this period $(106.5 \mathrm{~mm})$ was almost identical to the first cycle $(115.2 \mathrm{~mm})$, the rain was distributed more evenly, i.e. higher number of rain through the cycle, at more frequent intervals. There was a higher atmospheric demand, evidenced in higher $\mathrm{ET}_{0}$ in the second cycle, as can be seen in Table 1 .

It is possible to observe the accumulated evaporations on the period and their respective reductions in relation to the bare soil (Table 1).

In the second cycle the reduction of the evaporation was about $15 \%$ for treatment with $2.5 \mathrm{tha}^{-1}$, while for 5 and $10 \mathrm{tha}^{-1}$ approached 22 and $25 \%$, respectively. The treatment that resulted in the largest reduction of evaporation was of $10 \mathrm{tha}^{-1}$.

\section{Coefficient of evaporation (Ke)}

The coefficients of cultivation may be adjusted to consider separately the effects of evaporation and transpiration by the method of dual or combined Kc (ALLEN et al., 2005). In this case, two coefficients are used: the basal crop coefficient $\left(\mathrm{K}_{\mathrm{cb}}\right)$ to consider the conditions of transpiration in conditions of absence of water stress and coefficient of evaporation (Ke) for estimating the effect of evaporation from the soil surface.

As in this study the soil was kept under fallow, Ke is obtained by the ratio between the evaporation of soil water, occurred on the treatments, and the ETo. Ke values for different densities of soil coverage with straw in the two cycles are shown in Table 2.

There was a large increase in Ke of all treatments immediately after rainfall, due to the high surface soil humidity that contributes to increased evaporation.

The same occurs with Ke on the second cycle. They increase after the rains, because the humidity is high. The Ke, by expressing a direct relation between E and ETo, suffers the same effects discussed in evaporation.

In ANDRADE et al. (2007), with the presence of straw on surface in treatments 3 and $6 \mathrm{tha}^{-1}$ for maize residues, the maximum values of Ke were reduced to approximately $50 \%$ when compared with the treatments without straw on the surface reaching values of 0.70 and 0.44 , respectively. 
TABLE 2. Daily values of Ke under three densities of wheat straw.

\begin{tabular}{|c|c|c|c|c|c|c|c|c|c|}
\hline \multicolumn{6}{|c|}{$\begin{array}{c}1^{\text {st }} \text { Cycle } \\
\text { t ha }^{-1}\end{array}$} & \multicolumn{4}{|c|}{$\begin{array}{c}2^{\text {nd }} \text { Cycle } \\
\text { t ha }^{-1}\end{array}$} \\
\hline Date & 0 & 2.5 & 5 & 10 & Date & 0 & 2.5 & 5 & 10 \\
\hline $09 / 22 / 2008$ & 1.1 & 1.1 & 0.5 & 0.3 & $12 / 01 / 2008$ & 0.9 & 0.6 & 0.4 & 0.5 \\
\hline $09 / 23 / 2008$ & 0.5 & 0.4 & 0.5 & 0.4 & $12 / 02 / 2008$ & 0.9 & 0.6 & 0.7 & 0.5 \\
\hline 09/24/2008 & 0.4 & 0.4 & 0.4 & 0.2 & $12 / 03 / 2008$ & 0.9 & 0.8 & 0.7 & 0.4 \\
\hline $09 / 25 / 2008$ & 0.5 & 0.3 & 0.4 & 0.2 & $12 / 04 / 2008$ & 0.6 & 0.5 & 0.5 & 0.3 \\
\hline 09/26/2008 & 0.3 & 0.3 & 0.5 & 0.5 & $12 / 05 / 2008$ & 0.5 & 0.4 & 0.5 & 0.3 \\
\hline 09/27/2008 & 0.3 & 0.3 & 0.4 & 0.2 & $12 / 06 / 2008$ & 0.4 & 0.4 & 0.4 & 0.3 \\
\hline 09/28/2008 & 0.4 & 0.3 & 0.5 & 0.4 & $12 / 07 / 2008$ & 0.3 & 0.3 & 0.3 & 0.3 \\
\hline 09/29/2008 & 0.3 & 0.3 & 0.3 & 0.1 & $12 / 08 / 2008$ & 0.3 & 0.3 & 0.3 & 0.3 \\
\hline 09/30/2008 & 0.4 & 0.2 & 0.3 & 0.3 & $12 / 09 / 2008$ & 0.4 & 0.3 & 0.3 & 0.3 \\
\hline $10 / 01 / 2008$ & 0.3 & 0.1 & 0.4 & 0.4 & $12 / 10 / 2008$ & 0.5 & 0.4 & 0.3 & 0.3 \\
\hline $10 / 02 / 2008$ & 0.7 & 0.7 & 0.7 & 0.9 & $12 / 11 / 2008$ & 0.8 & 0.6 & 0.5 & 0.6 \\
\hline $10 / 03 / 2008$ & 0.8 & 0.9 & 0.6 & 0.8 & $12 / 12 / 2008$ & 0.6 & 0.6 & 0.5 & 0.4 \\
\hline $10 / 04 / 2008$ & 0.6 & 0.3 & 0.6 & 0.7 & $12 / 13 / 2008$ & 0.4 & 0.5 & 0.4 & 0.4 \\
\hline $10 / 05 / 2008$ & 0.8 & 3.1 & 1.0 & 2.3 & $12 / 14 / 2008$ & 0.3 & 0.3 & 0.3 & 0.3 \\
\hline $10 / 06 / 2008$ & 0.8 & 1.3 & 0.4 & 1.4 & $12 / 15 / 2008$ & 0.5 & 0.3 & 0.4 & 0.4 \\
\hline $10 / 07 / 2008$ & 0.6 & 0.7 & 0.3 & 0.4 & $12 / 16 / 2008$ & 1.0 & 0.7 & 0.5 & 0.7 \\
\hline $10 / 08 / 2008$ & 1.2 & 0.9 & 0.5 & 0.2 & $12 / 17 / 2008$ & 1.0 & 0.7 & 0.6 & 0.7 \\
\hline $10 / 09 / 2008$ & 0.7 & 0.6 & 0.5 & 0.1 & $12 / 18 / 2008$ & 0.7 & 0.7 & 0.4 & 0.5 \\
\hline $10 / 10 / 2008$ & 0.5 & 0.5 & 0.5 & 0.4 & $12 / 19 / 2008$ & 0.6 & 0.6 & 0.9 & 1.0 \\
\hline $10 / 11 / 2008$ & 0.0 & 0.2 & 0.2 & 0.1 & $12 / 20 / 2008$ & 0.4 & 0.4 & 0.4 & 0.5 \\
\hline $10 / 12 / 2008$ & 0.6 & 0.5 & 0.6 & 0.5 & $12 / 21 / 2008$ & 0.3 & 0.3 & 0.4 & 0.5 \\
\hline $10 / 13 / 2008$ & 0.4 & 0.3 & 0.4 & 0.4 & $12 / 22 / 2008$ & 0.3 & 0.3 & 0.3 & 0.5 \\
\hline $10 / 14 / 2008$ & 0.4 & 0.3 & 0.4 & 0.5 & $12 / 23 / 2008$ & 0.3 & 0.2 & 0.3 & 0.5 \\
\hline $10 / 15 / 2008$ & 0.7 & 0.6 & 0.6 & 0.5 & $12 / 24 / 2008$ & 0.3 & 0.3 & 0.3 & 0.5 \\
\hline $10 / 16 / 2008$ & 0.5 & 0.5 & 0.4 & 0.4 & $12 / 25 / 2008$ & 0.8 & 0.5 & 0.5 & 0.6 \\
\hline $10 / 17 / 2008$ & 0.4 & 0.5 & 0.4 & 0.3 & $12 / 26 / 2008$ & 0.9 & 0.7 & 0.8 & 0.9 \\
\hline $10 / 18 / 2008$ & 0.6 & 0.4 & 0.5 & 0.4 & $12 / 27 / 2008$ & 1.1 & 0.8 & 0.8 & 0.9 \\
\hline $10 / 19 / 2008$ & 0.6 & 0.6 & 0.5 & 0.3 & $12 / 28 / 2008$ & 0.5 & 0.6 & 0.5 & 0.7 \\
\hline \multirow[t]{2}{*}{$10 / 20 / 2008$} & 0.4 & 0.3 & 0.4 & 0.1 & $12 / 29 / 2008$ & 0.5 & 0.4 & 0.6 & 0.8 \\
\hline & & & & & $12 / 30 / 2008$ & 0.5 & 0.5 & 0.6 & 0.8 \\
\hline
\end{tabular}

MUTZIGER et al. (2005) compared the model presented in the FAO-56 Bulletin with values of soil water evaporation measured in lysimeter, the Ke values found corroborate with the values found in this experiment, after a rain, when the values are higher than 1.0. However, SNYDER et al. (2000) found Ke values ranging from 0.61 to 0.90 in studies performed in California.

Also OLIVEIRA et al. (2003) determined the coefficient of the carrot culture using the methodology proposed in the FAO 56 Bulletin. They observed Ke values higher than 1.0 in the initial phase of the culture after rain or irrigation.

It is observed in Table 2 that Ke values were superior than 1.0 to a few days, despite the rain occurred during the experimental period as it can be seen in Figures 2 and 3.

\section{CONCLUSIONS}

Regarding the bare soil, the rates of water evaporation from the soil are reduced from 4 to $15 \%, 15$ to $22 \%$ and 24 to $25 \%$, due to the coverage of the soil with wheat straw in amounts of 2.5 ; 5 and 10 t/ha, respectively. 


\section{REFERENCES}

ALLEN, R.G.; PEREIRA, L.S.; RAES, D.; SMITH, M. Crop evapotranspiration - guidelines for computing crop water requirements. Rome: FAO, 1998. 300 p. (Irrigation and Drainage Paper, 56)

ALLEN, R. G.; PEREIRA, L. S.; SMITH, M.; RAES, D.; WRIGHT, J. L. FAO-56 dual crop coefficient method for estimating evaporation from soil and application extensions. Journal of Irrigation and Drainage Engineering, Madison, v.131, n.1, p.2-13, 2005.

ANDRADE, J. G.; CARLESSO, R.; SEGUÍ, J. P.; MARTINS, J. D.; BROETTO, T. Perdas de água por evaporação de um solo cultivado em sistema de plantio direto e convencional. In: CONGRESSO BRASILEIRO DE CIÊNCIA DO SOLO, 31., 2007, Gramado. Anais ... Gramado: Sociedade Brasileira de Ciência do solo, 2007. 1 CD-ROM.

CAMPECHE, L. F. S. M. Construção, calibração e análise de funcionamento de lisímetros de pesagem para determinação da evapotranspiração da cultura da lima acida 'Tahiti'(Citrus latifolia Tan.). 2002. 67 f. Tese (Doutorado) - Escola Superior de Agricultura "Luiz de Queiroz", Universidade de São Paulo, Piracicaba, 2002.

EMBRAPA. EMPRESA BRASILEIRA DE PESQUISA AGROPECUÁRIA. Centro Nacional de Pesquisa de Solos. Sistema brasileiro de classificação de solos. 2.ed. Rio de Janeiro, 2006. 306 p.

FARIA, R. T.; CAMPECHE, F. S. M.; CHIBANA, E. Y. Construção e calibração de lisímetros de alta precisão. Revista Brasileira de Engenharia Agrícola e Ambiental, Campina Grande, v.10, n.1, p. 237-242, 2006.

FREITAS, P. S. L.; MANTOVANI, E. C.; SEDIYAMA, G. C.; COSTA, L. C. Efeito da cobertura de resíduo da cultura do milho na evaporação da água do solo. Revista Brasileira de Engenharia Agrícola e Ambiental, Campina Grande, v.8, n.1, p.85-91, 2004.

GAVA, R.; FARIA, R. T.; FREITAS, P. S. L.; LENA, B. P. Retenção de umidade pela cobertura morta em sistema de plantio direto. In: CONGRESSO BRASILEIRO DE ENGENHARIA AGRÍCOLA, 38., 2009, Juazeiro e Petrolina. Anais ... Jaboticabal: Associação Brasileira de Engenharia Agrícola, 2009. 1.CD-ROM.

GONÇALVES, A. O.; FAGNANI, M. A.; PERES, J. G. Efeitos da cobertura do solo com filme de polietileno azul no consumo de água da cultura da alface cultivada em estufa. Engenharia Agrícola, Jaboticabal, v.25, n.3, p.622-631, 2005.

MUTZIGER, A.J.; BURT, C.M.; HOWES, D.J.; ALLEN, R.G. Comparison of Measured and FAO56 Modeled Evaporation from Bare Soil. Journal of Irrigation and Drainage Engineering, New York, v.131, n.1, p.59-72, 2005.

OLIVEIRA, R. A.; ROCHA, I. B.; SEDIYAMA, G. C.; PUIATTI, M.; CECON, P. R.; SILVEIRA, S. F. R. Coeficiente de cultura da cenoura irrigada nas condições edafoclimáticas do Alto Paranaíba, no Estado de Minas Gerais. Revista Brasileira de Engenharia Agrícola e Ambiental, Campina Grande, v.7, n.2, p.280-284, 2003.

PREVEDELLO, C. L.; LOYOLA, J. M. T. R. Modelagem numérica para o processo da evaporação da água do solo. Revista Brasileira de Ciência do Solo, Viçosa, v.29, n.5, p.669-675, 2005.

SEAB. Secretaria da Agricultura e do abastecimento do Paraná. Estimativa de safra. Disponível em: <http://www.seab.pr.gov.br/>. Acesso em: 15 out. 2010

SILVA, F. A. M.; PINTO, H. S.; SCOPEL, E.; CORBEELS, M.; AFFHOLDER, F. As palhadas de milheto e de milho apresentaram capacidade maior para armazenar água do que a da soja: 3,26, 3,24 e 2,62 g de água por g de palhada, respectivamente. Pesquisa Agropecuária Brasileira, Brasília, v.41, n.5, p.717-724, 2006. 
SILVA, F. C.; FOLEGATTI, M. V.; PEREIRA, A. R.; VILLA NOVA, N. A. Uso de dispositivos lisimétricos para medida da evapotranspiração de referência. Revista Brasileira de Agrometeorologia, Santa Maria, v.7, n.1, p.19-23, 1999.

SNYDER, R.; BALI, K.; VENTURA, F.; GOMEZ-MACPHERSON, H. Estimating evaporation from bare or nearly bare soil. Journal of Irrigation and Drainage Engineering, New York, v. 126, n.6, p.399-403, 2000.

SOARES, W. R.; SEDIYAMA, G. C.; RIBEIRO, A.; COSTA, J. M. N. Dependência do coeficiente de cultura no estádio inicial de desenvolvimento $\left(\mathrm{Kc}_{\text {ini }}\right)$ à lâmina de irrigação e textura do solo. Revista Brasileira de Engenharia Agrícola e Ambiental, Campina Grande, v.5, n.1, p.23-27, 2001.

XIE, Z.; WANG, Y.; JIANG, W. WEI, X. Evaporation and evapotranspiration in a watermelon field mulched with gravel of different sizes in northwest China. Agricultural Water Management, Amsterdam, v.81, n.1, p.173-184, 2006. 